УДК 338.48

https://doi.org/10.52058/2708-7530-2021-9(15)-185-196

Подолян Михайло Іванович аспірант кафедри публічного управління та бізнес-адміністрування, Інститут післядипломної освіти та довузівської підготовки Прикарпатського національного університету ім. В. Стефаника, вул. Шевченка, 57, м. Івано-Франківськ, 76018, тел.: (0342) 75-23-51, е-mail: podoljan.mischa@gmail.com, https://orcid.org/0000-0002-0654-9382

Бурик Зоряна Михайлівна доктор наук з державного управління, доцент, професор кафедри публічного управління та бізнес-адміністрування, Інститут післядипломної освіти та довузівської підготовки Прикарпатського національного університету ім. В. Стефаника, вул. Шевченка, 57, м. ІваноФранківськ, 76018, тел.: (0342) 75-23-51, e-mail: z.burik@ukr.net, https://orcid.org/0000-0002-4394-6766

\title{
ТЕХНОЛОГІЇ УПРАВЛІННЯ ГОТЕЛЬНО-РЕСТОРАННОЇ СФЕРИ НА МІСЦЕВОМУ РІВНI
}

Анотація. У статті обгрунтовано актуальність питання збільшення функціонального навантаження на бізнес-структури в готельно-ресторанній сфері як передумови зростаючої необхідності у нових технологіях управління закладами сфери гостинності. Зокрема, зазначено, що потреба у використанні високотехнологічних інструментів управління пов'язана 3 наслідками глобалізації, появою технологічних, інформаційних та бізнес-інновацій, а отже, зі збільшенням інвестиційної привабливості галузі. Розглянуто готельноресторанний бізнес як складову туристичної індустрії світової економіки, визначено основні тенденції його розвитку, звернено увагу на світові проблеми ринку готельно-ресторанних послуг та висвітлено шляхи їх вирішення. Наведено розподіл закладів готельно-ресторанної сфери за ступенем інноваційності в регіонах України. Відзначено, що загалом рівень запровадження інноваційних технологій в готельному секторі, як правило, низький. Крім того, підкреслено, що результати дослідження підтверджують наявність прямого зв'язку між низькою конкурентоспроможністю вітчизняного готельного господарства та громадського харчування на світовому ринку, низьким рівнем поширення інформації про нього та незадовільним застосуванням інноваційних технологій у практиці управління. Здійснено оцінку ефективності готельно-ресторанного бізнесу в Україні для подальшого виявлення чинників впливу на індустрію гостинності. Досліджено нові тенденції розвитку готельно-ресторанної сфери, що зорієнтовані на споживача і дають можливість закладам відповідати сучасним вимогам та бути конкурентоспроможними на ринку. Розглянуто основні характеристики 
управління міжнародними мережами готелів та ресторанів, на які варто звернути особливу увагу для підвищення конкурентоспроможності українських закладів. Виділено основні проблеми вітчизняного готельно-ресторанного бізнесу. Досліджено перспективи розвитку готельно-ресторанного бізнесу в умовах глобалізації світового господарства.

Ключові слова: готельно-ресторанний бізнес, технології управління, інновації, ефективність управлінських процесів, регіональний рівень.

Podolyan Mykhailo Ivanovych Graduate student of the Department of Public Administration and Business Administration, Institute of Postgraduate Education and Pre-University Training of Prykarpattia National University. V. Stefanika, Shevchenko St., 57, Ivano-Frankivsk, 76018, tel.: (0342) 75-23-51, e-mail: podoljan.mischa@gmail.com, https://orcid.org/0000-0002-0654-9382

Buryk Zoryana Mykhailivna Doctor of science in public administration, Associate Professor, Professor of Public Administration and Business Administration, Institute of Postgraduate Education and Pre-University Training, Prykarpattia National University them. V. Stefanika, Shevchenko St., 57, Ivano-Frankivsk, 76018, tel.: (0342) 75-23-51, e-mail: z.burik@ukr.net, https://orcid.org/0000-0002-4394-6766

\section{TECHNOLOGIES OF HOTEL AND RESTAURANT MANAGEMENT AT THE LOCAL LEVEL}

Abstract. The article substantiates the urgency of the issue of increasing the functional load on business structures in the hotel and restaurant industry as a prerequisite for the growing need for new technologies for the management of hospitality institutions. In particular, it is noted that the need to use high-tech management tools is associated with the effects of globalization, the emergence of technological, informational and business innovations, and thus increase the investment attractiveness of the industry. The hotel and restaurant business as a component of the tourist industry of the world economy is considered, the main tendencies of its development are determined, attention is paid to the world problems of the market of hotel and restaurant services, and the ways of their solution are covered. The distribution of hotel and restaurant establishments according to the degree of innovation in the regions of Ukraine is given. It is noted that in general the level of introduction of innovative technologies in the hotel sector is usually low. In addition, it is emphasized that the results of the study confirm the direct link between the low competitiveness of the domestic hotel industry and catering in the world market, the low level of dissemination of information about it and the unsatisfactory use of innovative technologies in management. An assessment of the effectiveness of the hotel and restaurant business in Ukraine to further identify factors influencing the hospitality industry. New trends in the development of the hotel and restaurant industry, which are 
consumer-oriented and allow institutions to meet modern requirements and be competitive in the market. The main characteristics of the management of international hotel and restaurant chains are considered, which should be paid special attention to increase the competitiveness of Ukrainian institutions. The main problems of the domestic hotel and restaurant business are highlighted. Prospects for the development of hotel and restaurant business in the globalization of the world economy are studied.

Keywords: hotel and restaurant business, management technologies, innovations, efficiency of management processes, regional level.

Постановка проблеми. За сучасних умов ведення бізнесу розширення функціонального навантаження на бізнес-структури в готельно-ресторанній сфері пов'язане з наслідками глобалізації, появою технологічних, інформаційних та бізнес-інновацій, а отже, зі збільшенням інвестиційної привабливості галузі. Водночас, динамічність змін у зовнішньому середовищі призводить до посилення конкуренції, умов виживання та стійкості бізнес-структур у готельноресторанному господарстві.

Для ефективного функціонування та розвитку готельно-ресторанного закладу вже недостатньо мати добре налагоджені бізнес-процеси. 3 огляду на зростаючі темпи технологічних та суспільних змін, надзвичайно важливою $\epsilon$ здатність компанії швидко адаптуватися до нових умов та швидко приймати ефективні рішення. Дійсно, виживання готельного та ресторанного бізнесу в постіндустріальну епоху більше залежить від характеристик системи управління, аніж від ефективності системи виробництва, хоча останнє також $є$ надзвичайно важливим.

Аналіз останніх досліджень і публікацій. Вагомий внесок у вивчення проблем розвитку готельно-ресторанного бізнесу зробили вітчизняні науковці: О. Борисова, О. Бутенко, К. Гавриш, О. Головко, Н. Данько, Г. Круль, М. Мальська, I. Мініч, Л. Нечаюк, Я. Остапенко, О. Шаповалова, О. Юрченко та ін.

Вивчення окремих аспектів функціонування сфери готельно-ресторанних послуг на регіональному рівні наведені в роботах багатьох вітчизняних дослідників, зокрема серед них є I. Андренко, 3. Герасимчук, Н. Влащенко, К. Галасюк, І. Писаревський, Л. Черчик, С. Амандо, А. Аттала, С. Вукосав, М. Віснома, О. Лаптєва та ін.

Варто зазначити, що, не зважаючи на велику кількість наукових праць в даній сфері, більшість досліджень з цієї тематики були виконані в основному на теоретичному рівні, що обмежує можливості їх застосування на практиці. Отже, 3 урахуванням глобалізації світового господарства, питання розвитку ринку готельно-ресторанних послуг на місцевому рівні в Україні залишаються недостатньо вивченими і потребують додаткового дослідження.

Мета статті полягає у визначенні особливостей менеджменту підприємств готельно-ресторанного комплексу на регіональному рівні та розробленні рекомендацій з оптимізації управлінських механізмів. 
Виклад основного матеріалу. В сучасних умовах світовий ринок готельноресторанних послуг суттєво змінився через процеси глобалізації та інтеграції. В основному це пояснюється суворими умовами виживання, які передбачають активне впровадження новітніх технологій та науково-технічних досягнень у галузі гостинності. У той же час, готелі та заклади громадського харчування дуже популярні та затребувані, а тому вимагають високого рівня надання послуг та збільшення їх різноманітності для того, щоб залучити більше клієнтів.

Індустрія готельного господарства та громадського харчування є головною складовою туристичної індустрії, яка охоплює величезний спектр послуг, i тому $є$ суттєвим чинником розвитку туристичної галузі та визначає перспективи іï розвитку.

Сьогодні регіональний туризм неухильно зростає. Туристичний сектор світової економіки створив 10,4\% світового ВВП (8272,3 млрд доларів США) у 2019 році, зайнятість населення світу у цій сфері становить 9,9\% або 313,0 мільйонів робочих місць [6]. Якщо аналізувати світові тенденції в даній сфері, то частка туризму становить $7,4 \%$ i посідає третє місце після нафти та нафтопродуктів (перше місце з часткою 8,9\%) та автомобільної промисловості (друге місце 3 часткою 7,7\%) [7].

Позитивний динамізм туристичної галузі свідчить про збільшення ії̈ частки у світовому експорті найближчим часом. Це спонукає готельний та ресторанний бізнес розробляти нові стратегії та реалізовувати їх за допомогою сучасних інноваційних технологій, які дозволяють ефективно управляти інформаційними ресурсами в умовах глобалізації світової економіки. 3 цієї причини індустрія готельного господарства та громадського харчування за останні десятиліття значно змінилася, основними тенденціями іiі розвитку стали: поява готельних мереж, поглиблення інституційної спеціалізації, розвиток малого бізнесу, впровадження комп'ютерних технологій, охорона навколишнього середовища, орієнтація тощо [2, с. 293].

Необхідно визначити конкретні умови та чинники успішного функціонування підприємницьких структур вітчизняного ринку готельного бізнесу та сфери громадського харчування, які стримують зростання конкурентоспроможності галузі [8].

У сучасних умовах в Україні зростає конкуренція, внаслідок чого керівники підприємств постійно шукають нові ефективні технології управління бізнесом та важелі для підвищення конкурентоспроможності бізнес-структур. Чітких рекомендацій щодо розробки концепції розвитку готелів та ресторанів немає, рішення можуть бути різноманітними і здебільшого залежать від творчого потенціалу менеджера. Водночас при розробці концепції готелю чи ресторану слід враховувати такі фактори: якість надання послуг, їх унікальність, необхідні рівні управлінських повноважень, наявність ефективної політики знижок, ефективність практичної сторони справи.

Історія розвитку готельного та ресторанного бізнесу в сучасній Україні 
порівняно коротка - всього близько 20-ти років, але за ці роки цей бізнес пройшов шлях, який розвинуті країни проходять протягом багатьох десятиліть.

Великі компанії, особливо міжнародні готельні мережі, запроваджують найбільш прогресивні інноваційні технології управління готельно-ресторанним бізнесом на всій території Україні. У рамках франчайзингу або контрактів на управління ними впроваджуються більш сучасні технологічні системи, порівняно 3 іншими компаніями, а їх управлінський склад має якісно новий рівень освіти, що також означає володіння певними технологіями.

Однак, можна стверджувати, що загалом рівень запровадження інноваційних технологій в готельному секторі, як правило, низький. Застосування регіональної методології розподілу закладів цього сектору в Україні за ступенем інноваційності дозволило визначити, що лише близько $1 \%$ готелів можуть відноситись до інноваторів 5-го та вищого рівня, і майже всі вони зосереджені у столиці, м. Львові, м. Харкові; близько 5\% - це інноватори 4-го рівня, представлені в основному великими готелями в обласних центрах і великих приморських районах, 7\% відносяться до 3-го рівня інноваційності, а решта закладів на сьогодні перебуває на низькому рівні застосування інноваційних технологій (табл. 1).

Таблиия 1

\section{Розподіл закладів готельно-ресторанної сфери за ступенем інноваційності в регіонах України}

\begin{tabular}{|l|c|l|}
\hline \multicolumn{1}{|c|}{$\begin{array}{c}\text { Рівень інноваційності } \\
\text { технологій управління }\end{array}$} & $\begin{array}{c}\text { Питома вага готелів та } \\
\text { ресторанів в Україні }\end{array}$ & \multicolumn{1}{|c|}{ Регіони розташування } \\
\hline $\begin{array}{l}\text { Технології управління 5-го, } \\
\text { вищого рівня }\end{array}$ & $1 \%$ & м. Київ, м. Львів, м. Харків \\
\hline $\begin{array}{l}\text { Технології управління 4-го, } \\
\text { високого рівня }\end{array}$ & $\begin{array}{l}\text { Великі готелі в обласних } \\
\text { центрах і великих } \\
\text { приморських районах }\end{array}$ \\
\hline $\begin{array}{l}\text { Технології управління 3-го, } \\
\text { середнього рівня } \\
\text { інноваційності }\end{array}$ & $7 \%$ & Вся територія України \\
\hline $\begin{array}{l}\text { Технології управління } \\
\text { низького рівня } \\
\text { інноваційності }\end{array}$ & $87 \%$ & \\
\hline
\end{tabular}

Складено автором за даними [10].

Аналіз змісту веб-сайтів українських туристичних компаній у різних секторах ринку виявив низку проблем із використанням Інтернет-технологій на регіональному рівні, зокрема це неякісна орієнтація на клієнтів, не зручні пошукові системи, формалізований контент, погано розвинена система брендів, майже повністю відсутні мультимедійні технології, інструменти електронної 
комерції, мобільний та соціальний маркетинг.

Результати дослідження підтверджують наявність прямого зв'язку між низькою конкурентоспроможністю вітчизняного готельного господарства на світовому ринку, низьким рівнем поширення інформації про нього та незадовільним застосуванням інноваційних технологій у практиці управління [10].

Систематичне впровадження інноваційних технологій в готельному секторі та сфері громадського харчування в Україні полягає у створенні регіональних інноваційних інструментів як складових національної інноваційної системи таких технологій в Україні, прив'язаних до конкретної сфери регулювання з чіткими географічними межами, що обслуговують компанії, організації та окремих осіб, здатних до спільної роботи. Взаємодія між різними готельними та ресторанними мережами, створення власних та запозичення іноземних модифікованих технологій сприяють їх широкому розповсюдженню шляхом офіційної та неформальної взаємодії між об'єднаннями установ, організаціями та фізичними особами [1].

Формування у готельно-ресторанній сфері територіальних інноваційних систем управління на ранніх стадіях їх розробки та запровадження вимагає активного втручання держави, яка ініціює їх створення, об'єднує зусилля залучених осіб та створює умови для фінансування даних механізмів. При цьому інноваційна політика інтегрується у систему «освітня політика - дослідницька політика - технологічна політика - виробництво». На подальших стадіях запровадження та розвитку технологій управління у даній галузі вирішальна роль передається приватному сектору, а каталізатором інноваційних процесів $\epsilon$ соціальні та підприємницькі активні дії та ініціативність учасників системи [3].

Перехід до запровадження інновацій у технологіях управління в національній готельно-ресторанній сфері, створення ефективного регіонального туризму уповільнює низка внутрішніх умов у туристичному секторі України, що перешкоджають iï розвитку, зокрема, через низьку інституціоналізацію, несприятливу структуру ринку у більшості регіонів, через відсутність державноприватного партнерства в галузі громадського харчування, враховуючи низький рівень освіти фахівців даної сфери, відсутність зв'язків між науково-дослідними установами та компаніями, обмеженість доступу до фінансування, відсутність громадських ініціатив у даному секторі та поінформованості громадськості, підприємців.

На основі світового досвіду можна визначити такі стратегічні пріоритети для створення інноваційних технологічних систем, що забезпечують діяльність готелів та ресторанів в Україні як розвиток людського капіталу, включаючи підвищення кваліфікації кадрового складу на всіх рівнях управління, формування інноваційних ініціатив фахівців управлінської ланки та подолання їх опору інноваціям, максимальне наближення наявних освітніх пропозицій до потреб готельного та громадського харчування, встановлення тісних зв'язків між університетами та іншими навчальними закладами, що спеціалізуються на 
підготовці фахівців у сфері туризму; формування корпоративної культури на регіональному рівні, популяризація громадської роботи; поширення інновацій у готельному та ресторанному господарстві шляхом оцінки можливостей малого та середнього бізнесу для реалізації стратегічних ініціатив у сфері інновацій, просування наявних розробок, у тому числі шляхом державних закупівель, зрощування інноваційних ініціатив [5].

Важливими для розвитку таких технологій $\epsilon$ максимальна підтримка збільшення матеріальних та нематеріальних активів інноваційних компаній готельно-ресторанного бізнесу, сприяння розвитку підприємництва в наукових установах України, включаючи створення системних інноваційних технологій для готельного та громадського харчування та посилення співпраці між освітнім, науковим та промисловим сектором туризму; створення системи державноприватного партнерства в готельному секторі України; розширення інноваційної інфраструктури шляхом подальшого розвитку мережі туристичних інформаційних центрів як базового елементу інноваційної інфраструктури, розвитку мережі регіональних інноваційних центрів, сприяння створенню мережі регіональних та галузевих кластерів.

Загалом незначне використання інноваційних технологій компаніями готельного та громадського харчування на даний момент можна пояснити низкою проблем, що пов'язані з кадрами, нестачею коштів для розвитку та високим рівнем перешкод нормативного та ринкового характеру, з якими стикається підприємницький сектор.

Поширення інноваційних технологій на мікрорівні відбувається виключно через конкуренцію: національні компанії намагаються наслідувати традиції новаторів $з$ подібними інноваціями [4]. Зокрема, готельні та ресторанні заклади 3 високим рівнем якості управлінської практики у сфері стратегічного планування мають чітко визначену місію та мету. В управлінні ефективними компаніями застосовуються принципи об'єктивності, систематизованості та раціонального поєднання однобічності та демократії.

В процесі управління діяльністю таких компаній використовуються найбільш ефективні принципи та методи управління: організаційноадміністративний, економічний та соціально-психологічний, 3 акцентом на оптимізацію останньої групи методів. Переважним стилем управління в таких компаніях $\epsilon$ демократичний: децентралізований менеджмент, делегування повноважень на підтримку ініціативи, працівникам надається необхідна свобода для розвитку інновацій, новатори оснащені необхідними ресурсами та обладнанням, при чому розвивається корпоративна культура. У ефективних інноваційних компаніях здійснюється навчання персоналу та постійний обмін думками, підтримується ефективна комунікація з колегами, іншими підрозділами та зовнішніми організаціями. У структурі бізнесу цієї категорії компаній існує гнучкість в управлінні операціями, застосовується постійне підвищення компетентності команди, активізація службових відносин. 
В таких компаніях значну увагу приділяють підвищенню кваліфікації, при чому, особлива роль відводиться розвитку навичків міжкультурного, міжособистісного спілкування; звертається особлива увага на підвищення рівня культурного розвитку та обізнаності керівників та їх готовності брати на себе відповідальність у прийнятті рішень [9].

Залучення інвестиційних коштів має важливе значення для розвитку галузі готельного господарства та громадського харчування, але необхідною передумовою розвитку $\epsilon$ реалізація інноваційної стратегії, що забезпечує конкурентоспроможність закладу в майбутньому. Зрештою, не завжди вдається розрахувати на майбутне всі ймовірні ризики, щоб рухатися в правильному напрямку, а інвестори вважають за краще інвестувати у компанії з найменшим ризиком та найвищим терміном окупності [4].

Нинішня індустрія готельно-ресторанної сфери в Україні ще не відповідає вимогам міжнародних стандартів. Аналізуючи діяльність вітчизняних готельноресторанних закладів, доцільним є визначити основні їх проблеми: недостатній рівень розвитку рестораної сфери, де подають страви української регіональної кухні, швидке будівництво закладів готелів та ресторанів для масштабних заходів, використання яких не враховує інфраструктуру місцевостей, застарілість обладнання, споживання екологічно небезпечної сировини, порушення вимог щодо дотримання технології процесів виробництва харчових продуктів, неефективну підготовку фахівців у цій галузі, надмірні витрати на супутні послуги [7, с. 99].

Таким чином, на ефективність управління сферою комерційної гостинності впливає багато факторів, але особливу увагу слід приділити тим, від яких залежить репутація бізнесу. Зазвичай їх групують відповідно до певних напрямків, а саме: продукт, місце розташування, обладнання, рівень обслуговування, співвідношення ціни та якості, імідж, екологічність та доступність послуг, інновації, що забезпечують позитивне сприйняття готелю чи ресторану. Саме ступінь ефективності управління цими чинниками характеризує діяльність установи та впливає на результати діяльності. Розвиток індустрії готельного бізнесу та громадського харчування в Україні $є$ перспективним напрямком через сприятливі умови та багаті рекреаційні ресурси, але на даний момент все ще існує багато проблем у законодавчій базі та має місце нестабільна економічна та політична ситуація в країні, що уповільнює роботу готельної галузі та підприємств громадського харчування. Тому все ж головними чинниками, що впливають на дану галузь, залишаються економічна та політична ситуації, оновлення та вдосконалення законодавчої бази, що регулює дану сферу, якість управління у сфері готельного та громадського харчування.

Подальший розвиток індустрії готельного бізнесу та сфери громадського харчування в Україні включає не лише аналіз, а й планування та прогнозування на майбутне розвитку цієї галузі, починаючи 3 аналізу внутрішнього та зовнішнього середовища, визначення загальної стратегії компаній, врахування 
сучасних вимог, виявлення особливих властивостей i, виходячи 3 цього, розробка стратегії та вироблення концепцій, опрацювання бізнес-планів, програм і нарешті -процес реалізації проекту. Одночасно необхідно розпочати оновлення продуктового ряду, техніко-економічного рівня обслуговування для подальшого підвищення його якості та конкурентоспроможності компаній, а також звернути увагу на якість знань та міжнародну конкурентоспроможність надання послуг. Щоб бути лідером на ринку готельних та ресторанних послуг та отримати конкурентні переваги, потрібно використовувати комп'ютерні технології, Інтернет-технології, застосовувати наскрізну автоматизацію всіх бізнес-процесів [8, с. 188]. Найближчим часом готельний та ресторанний бізнес в Україні повинен зростати завдяки якості та оригінальності пропонованих послуг, і це стосується не лише мережевих компаній, а й середнього та малого бізнесу. Існуючі компанії повинні створювати мережі з універсальним набором послуг та високим рівнем обслуговування, що дозволяє їм домінувати на ринку. Необхідно створити сприятливий інвестиційний клімат на всіх рівнях для залучення іноземних та внутрішніх інвестицій, а також залучити державу до підтримки великих інвестиційних проектів. Тільки за таких умов розвитку готельноресторанна сфера в Україні може стати рівноправним учасником світового ринку.

Висновки. Таким чином, сучасний світовий ринок готельних та ресторанних послуг давно сформований, він функціонує в більшості країн світу на основі значної матеріально-технічної бази і постійно розвивається, забезпечуючи роботу мільйонам людей, що позитивно впливає на економіку країн. Діяльність готельного та ресторанного господарства в Україні обмежена такими факторами, як некомпетентність персоналу, несправне програмне забезпечення та відсутність системи захисту інформації, незадовільний рівень культури спілкування, недотримання екологічних та гігієнічних норм, неефективне ціноутворення, брак ресурсів, відсутність ефективних іміджевих заходів, відповідного законодавства. Крім того, економічна та політична нестабільність, обмежена платоспроможність населення та недосконала податкова система знизили конкурентоспроможність готельного господарства в країні. Тому готельний та ресторанний бізнес в Україні розвивається повільно, хоча напрями його розвитку відповідають європейським тенденціям.

Доцільним буде зазначити, що для прийняття стратегічних бізнес-рішень для розвитку закладів сфери готельного та громадського харчування, визначаючи корпоративну стратегію, слід мати на увазі, що основними критеріями вибору споживачем готелю чи ресторану $є$ смакові якості продуктів та розташування закладу. Для довгострокового виживання компаній необхідно використовувати різноманітні маркетингові інструменти, включаючи бенчмаркінг, що став популярним нещодавно.

Дослідження показує, що український ринок готельних та ресторанних послуг має хороші перспективи. В останні роки галузь готельного господарства почала залучати все більше інвесторів з різних сфер бізнесу. Це пояснюється 
насамперед привабливістю цього ринку з точки зору економічного зростання, а також можливістю стабільного прибутку протягом усього терміну роботи готелю чи ресторану за належного рівня управління (громадське харчування та сфера гостинності є одними з найбільш ліквідних галузей економіки). Водночас, сфера готельно-ресторанного бізнесу несе багато ризиків для потенційних інвесторів. У нашій країні немає серйозного ринкового досвіду та багатовікових традицій розвитку галузі готельного господарства та громадського харчування. Крім того, немає розробленої методологічної бази, яка б допомагала вести такий бізнес. Що ще гірше, готель чи ресторан як джерело доходу з точки зору багатьох інвесторів не вимагають особливих інвестицій та підходів до управління закладом.

Враховуючи світовий досвід, можна визначити пріоритетні напрями розвитку готельно-ресторанного бізнесу:

- враховуючи глобалізацію світової економіки, створити регіональні, національні та міжнародні мережі;

- урізноманітнити спектр послуг та зосередитись на потребах та бажаннях клієнтів, персоналізувати якість надання послуг;

- поглибити концепцію та спеціалізацію готельного та ресторанного бізнесу;

технології.

впроваджувати у компаніях новітні інформаційні комп’ютерні

Для ефективної роботи готелю та ресторану необхідно впровадити автоматизовані управлінські інформаційні системи, які дають змогу реалізувати ресурсозберігаючі та енергозберігаючі програми, підвищувати кваліфікацію обслуговуючого персоналу та продуктивність їх роботи, покращувати якість обслуговування.

Головною метою розвитку готельно-ресторанного бізнесу має бути пошук нових шляхів, які забезпечать прогрес цієї галузі не тільки в короткостроковій перспективі, а й у глобальному просторі в довгий період. Подальші дослідження передбачають використання всіх можливостей покращення якості обслуговування та конкурентоспроможності сфери гостинності в Україні шляхом впровадження позитивного зарубіжного досвіду у розвиток готельно-ресторанної сфери.

\section{Лimepamypa:}

1. Мацеха Д.С., Бурий С.А. Маркетинг у сфері готельно-ресторанного бізнесу та туризму // Вісник Хмельницького національного університету. - 2014. - № 5, Т. 2. - С. 43-47.

2. Керанчук Т. Особливості та напрями державного регулювання діяльності підприємств готельного та ресторанного бізнесу в Україні // Збірник наукових праць Черкаського державного технологічного університету. Серія «Економічні науки». - 2014. - № 36. - С. 112-118.

3. Кравченко О.М., Водянська Н.А. Управління конкурентоспроможністю підприємств ресторанного господарства // Матеріали IV науково-практичної Інтернет-конференції «Проблеми ринку та розвитку регіонів України в XXI столітті» (Одеса, 12-19 грудня 2013 р.). Одеса: ОНПУ, 2013. - С. 54-56. 
4. Чумак О.В., Андрущенко I.C. Аналіз стану й оцінка тенденцій показників розвитку підприємств ресторанного господарства // БізнесІнформ. - 2014. - № 12. - С. 307-313.

5. Юрченко О. Інновації в готельному бізнесі на сучасному етапі // Вісник Львівського університету. Серія «Міжнародні відносини». - 2014. - Вип. 34. - С. 292-300.

6. Статистичний щорічник України за 2019 рік. Режим доступу: http://www.ukrstat.gov.ua

7. Галасюк С.С. Досвід європейських країн у застосуванні стандартів «HOTELSTARS UNION» // Матеріали круглого столу та студентської науково-практичної конференції «Туристичний та готельно-ресторанний бізнес: світовий досвід та перспективи розвитку для України». Одеса, 2019. - С. 13-18.

8. Основи готельно-ресторанної справи: навчальний посібник. Н.І. Данько та ін.; за заг. ред. А.Ю. Парфененка. Харків: ХНУ імені В.Н. Каразіна, 2017. - 288 с.

9. Лінтур І.В. Інноваційний потенціал у сфері готельно-ресторанного бізнесу. Режим доступу: http://dspace.msu.edu.ua:8080/bitstream/.

10. Перепелиця А.С. Регулювання готельного бізнесу в умовах інформатизації глобального економічного простору // Вісник. Серія «Міжнародні відносини. Економіка. Країнознавство. Туризм». - 2017. - Вип. 6. - С. 187-190.

\section{References:}

1. Maceha, D. (2014). Marketing u sferi gotel'no-restorannogo biznesu ta turizmu [Marketing in the field of hotel and restaurant business and tourism], Visnik Hmel'nic'kogo nacional'nogo universitetu - Visnyk of Khmelnytsky National University, 5(2), 43-47 [in Ukrainian].

2. Keranchuk, T. (2014). Osoblivosti ta naprjami derzhavnogo reguljuvannja dijal'nosti pidpriemstv gotel'nogo ta restorannogo biznesu v Ukraïni [Peculiarities and directions of state regulation of hotel and restaurant business in Ukraine], Zbirnik naukovih prac' Cherkas'kogo derzhavnogo tehnologichnogo universitetu. Serija «Ekonomichni nauki» - Collection of scientific works of Cherkasy State Technological University. Economic Sciences Series, 36, 112-118 [in Ukrainian].

3. Kravchenko, O., \& Vodjans'ka, N. (2013). Upravlinnja konkurentospromozhnistju pidpriemstv restorannogo gospodarstva [Management of competitiveness of enterprises of the restaurant industry], Materiali IV naukovo-praktichnoï Internet-konferencï «Problemi rinku ta rozvitku regioniv Ukraïni $v$ HHI stolitti» - Proceedings of the IV scientific-practical Internet conference "Problems of the market and development of regions of Ukraine in the XXI century" (Odesa, 12-19 grudnja 2013 r.). Odesa, 54-56 [in Ukrainian].

4. Chumak, O., \& Andrushhenko, I. (2014). Analiz stanu j ocinka tendencij pokaznikiv rozvitku pidpriemstv restorannogo gospodarstva [Analysis of the state and assessment of trends in the development of restaurants], BiznesInform - BiznesInform, 12, 307-313 [in Ukrainian].

5. Jurchenko, O. (2014). Innovaciï v gotel'nomu biznesi na suchasnomu etapi [Innovations in the hotel business at the present stage], Visnik L'vivs'kogo universitetu. Serija «Mizhnarodni vidnosini»Visnyk of Lviv National University. International Relations Series, 34, 292-300 [in Ukrainian].

6. Statistichnij shhorichnik Ukraïni za 2016 rik. [Statistical Yearbook of Ukraine for 2019]. Retrieved from http://www.ukrstat.gov.ua [in Ukrainian].

7. Galasjuk, S. (2019). Dosvid evropejs'kih kraïn u zastosuvanni standartiv «HOTELSTARS UNION» [Experience of European countries in the application of HOTELSTARS UNION standards], Materiali kruglogo stolu ta students'koï naukovo-praktichnoï konferenciï «Turistichnij ta gotel'norestorannij biznes: svitovij dosvid ta perspektivi rozvitku dlja Ukraïni» - Proceedings of the round table and student scientific-practical conference "Tourism and hotel and restaurant business: world experience and prospects for development for Ukraine", Odesa, 13-18 [in Ukrainian].

8. Dan'ko, N. (2017). Osnovi gotel'no-restorannoï spravi: navchal'nij posibnik. Harkiv: HNU imeni V.N. Karazina. 288 s. [in Ukrainian]. 
9. Lintur, I. Innovacijnij potencial u sferi gotel'no-restorannogo biznesu [Innovative potential in the field of hotel and restaurant business]. Retrieved from http://dspace.msu.edu.ua:8080/bitstream/ [in Ukrainian].

10. Perepelicja, A. (2017) Reguljuvannja gotel'nogo biznesu v umovah informatizaciï global'nogo ekonomichnogo prostoru [Reguljuvannja gotel'nogo biznesu v umovah informatizaciï global'nogo ekonomichnogo prostoru], Visnik. Serija «Mizhnarodni vidnosini. Ekonomika. Kraïnoznavstvo. Turizm»-Visnyk. Series "International Relations. Economy. Local lore. Tourism", 6, 187-190 [in Ukrainian]. 